\title{
Molecular Characterization of Divergent Closterovirus Isolates Infecting Ribes Species
}

\author{
Igor Koloniuk $^{1}{ }^{(1)}$, Thanuja Thekke-Veetil ${ }^{2}$, Jean-Sébastien Reynard ${ }^{3}$ (i), Irena Mavrič Pleško ${ }^{4}$, \\ Jaroslava Přibylová ${ }^{1}$, Justine Brodard ${ }^{3}$, Isabelle Kellenberger ${ }^{3}$, Tatiana Sarkisova ${ }^{1}$, Josef Špak ${ }^{1}$, \\ Janja Lamovšek ${ }^{4}$, Sebastien Massart ${ }^{5}$, Thien Ho ${ }^{2}$, Joseph D. Postman ${ }^{6}$ \\ and Ioannis E. Tzanetakis 2 (iD \\ 1 Department of Plant Virology, Institute of Plant Molecular Biology, Biology Centre of the Academy of \\ Sciences of the Czech Republic, v.v.i., Branišovská 31, 37005 České Budějovice, Czech Republic; \\ koloniuk@umbr.cas.cz (I.K.); pribyl@umbr.cas.cz (J.P.); sarkisova@umbr.cas.cz (T.S.); spak@umbr.cas.cz (J.Š.) \\ 2 Department of Plant Pathology, Division of Agriculture, University of Arkansas System, \\ Fayetteville, AR 72701, USA; thanujatv@gmail.com (T.T.-V.); txho@uark.edu (T.H.); itzaneta@uark.edu (I.E.T.) \\ 3 Virology-Phytoplasmology Laboratory, Agroscope, 1260 Nyon, Switzerland; \\ jean-sebastien.reynard@agroscope.admin.ch (J.-S.R.); justine.brodard@agroscope.admin.ch (J.B.); \\ isabelle.kellenberger@agroscope.admin.ch (I.K.) \\ 4 Agricultural Institute of Slovenia, Hacquetova ulica 17, 1000 Ljubljana, Slovenia; \\ irena.mavricplesko@kis.si (I.M.P.); janja.lamovsek@kis.si (J.L.) \\ 5 Plant Pathology Laboratory, TERRA-Gembloux Agro-Bio Tech, University of Liège, Passage des Déportés, 2, \\ 5030 Gembloux, Belgium; sebastien.massart@uliege.be \\ 6 National Clonal Germplasm Repository, United States Department of Agriculture, Corvallis, OR 97333, USA; \\ joseph.postman@ars.usda.gov \\ * Correspondence: koloniuk@umbr.cas.cz; Tel.: +42-038-777-5531
}

Received: 15 June 2018; Accepted: 10 July 2018; Published: 12 July 2018

\begin{abstract}
Five isolates of a new member of the family Closteroviridae, tentatively named blackcurrant leafroll-associated virus 1 (BcLRaV-1), were identified in the currant. The 17-kb-long genome codes for 10 putative proteins. The replication-associated polyprotein has several functional domains, including papain-like proteases, methyltransferase, Zemlya, helicase, and RNA-dependent RNA polymerase. Additional open reading frames code for a small protein predicted to integrate into the host cell wall, a heat-shock protein 70 homolog, a heat-shock protein 90 homolog, two coat proteins, and three proteins of unknown functions. Phylogenetic analysis showed that BcLRaV-1 is related to members of the genus Closterovirus, whereas recombination analysis provided evidence of intraspecies recombination.
\end{abstract}

Keywords: Ribes; currant; closterovirus; recombinants/recombination

\section{Introduction}

Black and red currants (Ribes species (spp.)) are economically important berry crops. They are deciduous, unarmed shrubs native to the northern latitudes of Asia, Europe, and North America, and they belong to the subgenera Coreosma and Ribesia of the genus Ribes [1]. The genus includes more than 150 diploid species and numerous cultivated varieties [2]. Diseases caused by viruses and virus-like agents have been studied in currants from the beginning of last century [3-5]. New currant viruses were recently identified using traditional methods or high-throughput sequencing (HTS) [6-11].

Notwithstanding the progress in currant virology, there are gaps in the knowledge, one of which is addressed here through the characterization of a new closterovirus complex, affecting both black and red currants. Roberts and Jones observed closterovirus-like particles in Ribes in 1997 [12]. In 2010, Besse et al. observed similar particles in currants showing downward leaf rolling and 
interveinal reddening in the summer and autumn [6]. They produced antisera for serological detection, and designed primers allowing for the detection of two molecular variants of this virus. In 2015, Ho et al. reported a closterovirus in black currant in the USA and developed a molecular diagnostic assay for its detection [13].

The family Closteroviridae includes the genera Ampelovirus, Closterovirus, Crinivirus, and Velarivirus, with vectors ranging from mealybugs and soft scales to aphids and whiteflies [14,15]. The genome segments are encapsidated by two coat proteins (CPs) in characteristically long, flexuous particles [14]. Closterovirids have a five-gene block involved in virion assembly and movement that, in addition to two CPs, includes a small transmembrane protein, a $20 \mathrm{kDa}$ protein, and a HSP70 homolog [15]. Their host range is usually narrow, but the acquisition of accessory genes is believed to play a role in host-range expansion [15].

Here, we studied in depth a closterovirus species, tentatively named blackcurrant leafroll associated virus 1 (BcLRaV-1), identified in black and red currants including particle morphology, genome organization, and the evolutionary forces acting on the virus.

\section{Materials and Methods}

\subsection{Transmission Electron Microscopy}

Virus particles from isolate BC28074 were purified as described by Gugerli and Ramel [16] and observed using a Tecnai Spirit transmission electron microscope (TEM).

\subsection{Genome Assembly and Organization}

The genome of all isolates was obtained using a combination of HTS and Sanger sequencing in four labs and sequences deposited in GenBank (Table 1).

Table 1. Origin of currant isolates and the description of high-throughput sequencing (HTS).

\begin{tabular}{|c|c|c|c|c|c|}
\hline \multirow{2}{*}{$\begin{array}{l}\text { BcLRaV-1 Isolate/GenBank } \\
\text { Accession Number }\end{array}$} & \multirow{2}{*}{ Plant } & \multirow{2}{*}{ Origin } & \multirow{2}{*}{ Symptoms } & \multicolumn{2}{|c|}{ Sequencing } \\
\hline & & & & Input & HTS Output \\
\hline G55/MH460557 & $\begin{array}{l}\text { Red currant, } \\
\text { Gabreta } 55\end{array}$ & Czech Republic & Asymptomatic & \multirow{2}{*}{$\begin{array}{l}\text { Total RNA: } \\
\text { mRNA enriched }\end{array}$} & \multirow{2}{*}{$\begin{array}{l}20 \text { millions, } \\
100 \text { bp reads }\end{array}$} \\
\hline GR/MH460558 & $\begin{array}{c}\text { Red currant, } \\
\text { Gondouin Rouge }\end{array}$ & Czech Republic & Asymptomatic & & \\
\hline SLO/MH480582 & $\begin{array}{l}\text { Black currant, } \\
\text { unknown cultivar }\end{array}$ & Slovenia & Asymptomatic & $\begin{array}{l}\text { Total RNA: } \\
\text { Ribo-depleted }\end{array}$ & $\begin{array}{l}10 \text { millions, } 2 \times \\
150 \text { nt reads }\end{array}$ \\
\hline BC28074/MH541840 & $\begin{array}{l}\text { Black currant, } \\
28074\end{array}$ & Switzerland & Leafroll [6] & $\begin{array}{l}\text { Viral-associated } \\
\text { nucleic acid }\end{array}$ & $\begin{array}{c}50 \text { millions, } \\
2 \times 75 \text { nt reads }\end{array}$ \\
\hline US/MH500053 & $\begin{array}{l}\text { Black currant, } \\
\text { NCGR PI } 556169\end{array}$ & USA & $\begin{array}{l}\text { Yellow line } \\
\text { patterns [13] }\end{array}$ & $\begin{array}{c}\text { Enriched } \\
\text { double-stranded RNA }\end{array}$ & 76,214 reads \\
\hline
\end{tabular}

GR and G55: Four red currant accessions were extracted with the GeneJET Plant RNA Purification Kit (Thermo Fisher Scientific, Vilnius, Lithuania) and mRNA-enriched (TruSeq Stranded mRNA kit, Illumina, San Diego, CA, USA) before being subjected to HTS (SeqMe s.r.o., Dobřŕš, Czech Republic). Missing sequence segments were obtained by PCR amplification using the Q5 High-Fidelity Master Mix (NEB, Ipswich, MA, USA). The 5'-termini were completed and sequenced with a $5^{\prime}$ rapid amplification of complementary DNA (cDNA) ends (RACE) kit (Invitrogen, Carlsbad, CA, USA), and the $3^{\prime}$-ends were derived as previously described [17]. Sequence verification and gap-filling were done through Sanger sequencing of PCR amplicons or cloned into a pGEM T-Easy vector system (Promega, Road Madison, WI, USA).

SLO: Total RNA was extracted from $100 \mathrm{mg}$ of leaf tissue using an RNeasy Plant Mini Kit (Qiagen, Sverige, Denmark), in which RLT buffer was supplemented with a 10\% Plant RNA Isolation Aid (Thermo Fisher Scientific). The extracted total RNA was quantified on a Bioanalyzer 2000. Ribosomal RNA was depleted using a RiboMinus Plant Kit for RNA-Seq (Thermo Fisher Scientific), and total RNA libraries were then prepared following the manufacturer's instructions for a TrueSeq Stranded mRNA kit (Illumina), without the poly-A enrichment step. The RNA libraries were sequenced 
on a Nextseq 500 sequencing machine at the Liege University in Belgium, with a read length of $2 \times 150 \mathrm{nt}$. (Etiology fair COST Divas). Missing sequence fragments were PCR amplified using the Phusion Flash High Fidelity Master Mix (Thermo Fisher Scientific), and the PCR products were directly sequenced (Macrogen, Seoul, Korea).

BC28074: Virus particles were purified from mature leaves as previously described [18]. Subsequently, RNA was extracted using an RNeasy Plant Mini kit (Qiagen, Hilden, Germany). The library was prepared using the TrueSeq Stranded mRNA kit (Illumina) following the manufacturer's instructions and subjected to HTS on a HiSeq 4000 (Fasteris SA, Geneva, Switzerland). The 5'- and 3'-terminal sequences of BC28074 were obtained using a RACE system for the rapid amplification of cDNA ends (Invitrogen). At least two PCR amplicons were cloned and Sanger-sequenced.

US: HTS was performed on degenerate oligonucleotide-primed reverse-transcription-PCR (DOP RT-PCR) products derived from double-stranded RNA-enriched (dsRNA) material of the infected plant, following the procedures described previously [7]. Missing genome fragments were obtained via RT-PCR using virus-specific primers. The 5'-terminal sequences were obtained using a FirstChoice RLM-RACE Kit (Thermo Fisher Scientific), whereas the $3^{\prime}$-ends were obtained using RACE-RT-PCR on polyadenylated RNAs (Poly (A) Tailing Kit, Applied Biosystems, Foster City, CA, USA). All PCR products were sequenced so as to achieve at least three-fold coverage of the regions.

\subsection{In Silico Analyses}

Sequence analyses were done using a CLC Genomics Workbench 9.5.1 (Qiagen) and the Geneious 9.1.5 software (Biomatters Limited, Auckland, New Zealand). Transmembrane prediction was carried out using the TMHMM 2.0c tool (http:/ / www.cbs.dtu.dk/services/TMHMM/). Multiple sequence alignments were built with the Multiple Alignment using Fast Fourier Transform (MAFFT) program [19]. Phylogeny reconstructions were inferred using the maximum-likelihood method with an approximate likelihood ratio test for branches. The phylogenetic trees were visualized using the Interactive Tree of Life v3 tool [20]. Putative recombination events were detected and evaluated in the RDP4 program [21], using a MAFFT-built multiple alignment of the complete genome sequences.

\section{Results and Discussion}

\subsection{Sequence and Genome Organization}

The genomes of five isolates from Europe and North America, infecting both black and red currants, were reconstructed (Table 1). The genome lengths ranged from 16,996 to 17,313 nucleotides (nt) and coded for 10 open reading frames (ORFs; Figure 1 and Table 2), with genome organization being identical among isolates. The results of the $3^{\prime}$-RACE with virus-specific primers on GR and G55 suggested an absence of the poly(A) tail at the $3^{\prime}$-terminus, similar to other closteroviruses, and therefore the analysis was not repeated for the other isolates.

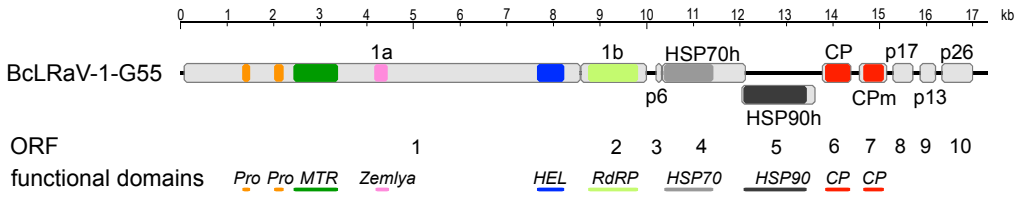

Figure 1. Schematic representation of the genomic organization of the Gabreta 55 (G55) isolate of blackcurrant leafroll associated virus 1 (BcLRaV-1-G55). The genome is drawn as a black line, and the predicted open reading frames (ORFs) are represented by shaded rectangles. Annotations, ORF numbers, and identified functional domains are given below. Abbreviations: Pro-papain-like leader proteinase, Zemlya — see text for description, MTR - methyltransferase, HEL-helicase, RdRP-RNA-dependent RNA polymerase, HSP70 - heat-shock protein 70, HSP90-heat-shock protein 90, CP — capsid protein, and $\mathrm{CPm}-$ minor capsid protein. 
Table 2. Genomic characteristics of the BcLRaV-1 isolates.

\begin{tabular}{|c|c|c|c|c|c|c|c|c|c|c|c|c|}
\hline \multirow{3}{*}{ Isolate } & \multirow{3}{*}{$\begin{array}{l}\text { Genome } \\
\text { Length } \\
\text { (nt) }\end{array}$} & \multicolumn{11}{|c|}{ Genome Elements } \\
\hline & & \multirow{2}{*}{$\begin{array}{c}5^{\prime} \text {-UTR } \\
\text { (nt) }\end{array}$} & \multirow{2}{*}{$\begin{array}{c}3^{\prime} \text {-UTR } \\
\text { (nt) }\end{array}$} & \multicolumn{9}{|c|}{$\begin{array}{l}\text { Length of ORFs for Predicted Proteins (nt)/ } \\
\text { Molecular Mass of Encoded Proteins (kDa) }\end{array}$} \\
\hline & & & & $1 \mathrm{a} / \mathbf{1 b}$ & p6 & HSP70h & HSP90 & $\mathrm{CP}$ & $\mathrm{CPm}$ & p17 & p13 & p26 \\
\hline G55 & 17,313 & 97 & 275 & $9939 / 371.9$ & $147 / 5.7$ & $1797 / 65.6$ & $1593 / 61$ & $636 / 23.6$ & $606 / 22.3$ & $456 / 16.8$ & $348 / 13.1$ & $690 / 25.6$ \\
\hline GR & 17,161 & 99 & 309 & $9906 / 370.5$ & $147 / 5.7$ & $1797 / 65.5$ & $1590 / 60.9$ & $636 / 23.6$ & $606 / 22.2$ & $441 / 16.3$ & $348 / 13.2$ & $690 / 25.8$ \\
\hline SLO & 16,894 & $1 *$ & $260 *$ & $9942 / 372.7$ & $150 / 5.6$ & $1797 / 65.7$ & $1593 / 60.6$ & $636 / 23.4$ & $606 / 22.5$ & $444 / 16.5$ & $372 / 14.3$ & $687 / 25.5$ \\
\hline BC28074 & 17,141 & 102 & 290 & $9942 / 370.3$ & $150 / 5.7$ & $1797 / 65.9$ & $1593 / 60.4$ & $636 / 23.5$ & $714 / 26.7$ & $444 / 16.4$ & $399 / 15$ & $687 / 25.6$ \\
\hline US & 16,996 & 99 & 264 & $9942 / 372.7$ & $150 / 5.6$ & $1797 / 65.7$ & $1593 / 60.7$ & $636 / 23.4$ & $606 / 22.5$ & $444 / 16.6$ & $372 / 14.2$ & $687 / 25.5$ \\
\hline
\end{tabular}

ORFs 1 and 2 encode the replication-associated proteins (Table 2), in which ORF2 is presumably translated via a +1 ribosomal frameshift from ORF1, a mechanism prevalent in closteroviruses [22], resulting in a fusion polyprotein $1 \mathrm{a} / 1 \mathrm{~b}$. The sequence surrounding the potential ribosome +1 slippage site is conserved in all isolates: $\mathrm{cg}(\mathrm{a} / \mathrm{g} / \mathrm{c})$ guuUAAcua (the stop codon of ORF1 is capitalized; the first proposed codon of ORF2 is underlined). A conserved domain search identified five replication-associated domains in the $1 \mathrm{a} / 1 \mathrm{~b}$ protein (Figure 1). Two copies of a papain-like leader proteinase (Pro; pfam05533) were found upstream of a methyltransferase motif (MTR; pfam01660). The copies were diverse, sharing only $21 \%$ to $30 \%$ amino acid (aa) identity within each isolate. While intragenome duplication of coat proteins is a fairly common feature of family members, two copies of the leader protease are present in some members of the genus Closterovirus. Duplication events are independent across species, followed by the functional divergence of each copy [23]. The roles of previously studied viral leader proteases are not only limited to self-processing (proteolysis), but also include the regulation of genome replication and transcription [24]. Host-specific effects were demonstrated for leader proteinases of grapevine leafroll-associated virus-2 (GLRaV-2) and particularly suggested that such diversification is needed for a closterovirus infection of perennial and/or woody plants [24].

A recently described "Zemlya" region was identified after the MTR domain (Figure 1), and presumably guides the remodeling of the endoplasmic reticulum membranes during infection, a process connected to the formation of viral replication factories [25]. The Zemlya region was predicted to form four $\alpha$-helices, and three strictly conserved positions were found in known closteroviruses [25]. The BcLRaV-1 isolates differed in one of the conserved positions, featuring a valine instead of a proline residue (Figure 2). This change is noteworthy, as the $\alpha \mathrm{D}$ region was predicted to form an amphipathic helix, and the proline, being strongly disfavored in helices, could induce a kink in the helix [25].

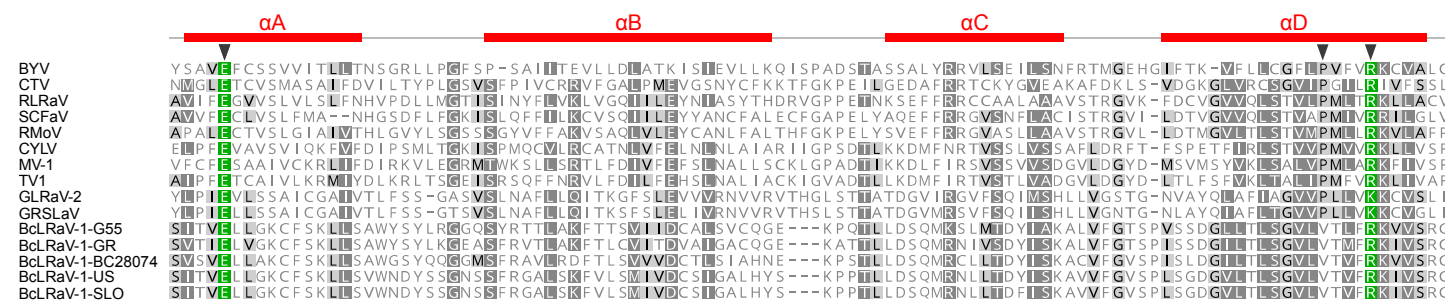

Figure 2. Multiple alignment of the Zemlya-region sequences of beet yellows virus (BYV, NC_001598), citrus tristeza virus (CTV, AB046398), rose leaf rosette-associated virus (RLRaV, NC_024906), strawberry chlorotic fleck-associated virus (SCFaV, NC_008366), raspberry mottle virus (RMoV, NC_008585), carrot yellow leaf virus (CYLV, NC_013007), mint virus 1 (MV-1, NC_006944), tobacco virus 1 (TV1, NC_027712), grapevine leafroll-associated virus 2 (GLRaV-2, NC_007448), grapevine rootstock stem lesion-associated virus (GRSLaV, NC_004724), BcLRaV-1-G55 (MH460557), BcLRaV-1-GR (MH460558), BcLRaV-1-BC28074 (MH541840), BcLRaV-1-US (MH500053), and BcLRaV-1-SLO (MH480582). Gaps are shown as dashes. Black triangles indicate conserved positions. Previously predicted [25] secondary structure is shown above the alignment. 
The C-proximal part of the 1a/1b protein contains a viral helicase (HEL; superfamily 1, pfam01443) and an RNA-dependent RNA polymerase (RdRP; pfam00978). Together with the MTR domain located at the $1 \mathrm{a} / 1 \mathrm{~b}$-terminus, they constitute a replication module conserved across the entire alphavirus superfamily [26]. In other closteroviruses, a large region between the MTR and HEL domains is believed to be cleaved by either an unidentified viral or cellular protease [27]. The putative ORF3 encodes a $\mathrm{p} 6$ protein with a predicted transmembrane domain. The $\mathrm{p} 6$ counterpart in beet yellows virus (BYV) is associated with the endoplasmic reticulum, and it functions as a cell-to-cell movement protein [28]. It is separated by a short intergenic region from the putative heat-shock protein 70 homolog (HSP70h; cd10170). The HSP70h of BYV and other closteroviruses is an integral part of the virion, and it plays a role in cell-to-cell movement through its ATPase activity [15]. ORF5, coding for an HSP90h-like protein (pfam03225), partially overlaps the 3 '-proximal region of ORF4. Two putative structural proteins, the major and minor capsid proteins (CP and CPm, respectively; (pfam01785)), are encoded by ORF6 and ORF7, respectively. The closterovirus CPm was shown to be essential for encapsidation of the $5^{\prime}$-region of the viral RNA. Downstream of the capsid proteins, closteroviruses encode a variable number of accessory proteins, and their functionality was determined only for some. For example, the p20 and p21 of BYV participate in systemic transport and the suppression of RNA silencing, respectively [22]. In the citrus tristeza virus (CTV), p23, a suppressor of RNA silencing, did not have any identifiable orthologs in other closteroviruses [29]. Similar to the majority of the studied closterovirids, the three predicted ORFs downstream of the capsid proteins (p17, p13, and p26) did not have significant (E-value cut-off: $10^{-3}$ ) similarity to other viral proteins and do not contain transmembrane domains.

\subsection{Divergence of $B c L R a V-1$}

Nucleotide divergence between the isolates reached 39\% (Figure 3). The black and red currant isolates showed divergence of $35 \%$ and $29 \%$ among them, respectively. For individual proteins, identities ranged from $45 \%$ for p13 to $83 \%$ for HSP70h.

\begin{tabular}{|c|c|c|c|c|c|c|c|c|c|c|c|}
\hline \multirow[t]{2}{*}{ Pair } & \multirow[t]{2}{*}{$\begin{array}{c}\text { Genome, } \\
\text { nt identity, \% }\end{array}$} & \multicolumn{10}{|c|}{$\begin{array}{c}\text { Gene, } \\
\text { aa identity, \% }\end{array}$} \\
\hline & & $1 a / 1 b$ & $p_{1} 6$ & HSP7Oh & HSP9O & $\mathrm{CP}$ & $\mathrm{CPm}$ & $\mathrm{p} 17$ & $\mathrm{p} 13$ & $\mathrm{p} 26$ & \\
\hline SLO vs US & 98 & 99 & 96 & 99 & 98 & 98 & 98 & 99 & 92 & 99 & \\
\hline $\mathrm{BC} 28074$ vs US & 65 & 63 & 63 & 84 & 78 & 85 & 80 & 61 & 47 & 76 & $50 \cong$ \\
\hline SLO vs BC28074 & 64 & 64 & 78 & 84 & 78 & 85 & 80 & 61 & 45 & 76 & $60 \frac{\bar{\alpha}}{0}$ \\
\hline SLO vs G55 & 61 & 62 & 71 & 79 & 66 & 78 & 78 & 52 & 32 & 62 & \\
\hline SLO vs GR & 61 & 62 & 78 & 79 & 67 & 76 & 77 & 51 & 31 & 63 & $80 \div$ \\
\hline GR vs US & 61 & 62 & 73 & 79 & 67 & 76 & 78 & 51 & 31 & 62 & 90 \\
\hline GR vs BC28074 & 61 & 63 & 71 & 78 & 69 & 76 & 77 & 51 & 30 & 61 & \\
\hline G55 vs US & 61 & 62 & 67 & 79 & 66 & 78 & 77 & 52 & 31 & 62 & \\
\hline G55 vs BC28074 & 61 & 63 & 76 & 78 & 68 & 78 & 76 & 51 & 30 & 61 & \\
\hline G55 vs GR & 72 & 67 & 85 & 95 & 90 & 93 & 94 & 80 & 77 & 82 & \\
\hline aver & 67 & 67 & 76 & 83 & 75 & 82 & 82 & 61 & 45 & 70 & \\
\hline
\end{tabular}

Figure 3. Pairwise nucleotide and predicted amino acid (aa) protein identities among BcLRaV-1 isolates.

Noticeably, neither the predicted $1 \mathrm{~b}, \mathrm{HSP} 70 \mathrm{~h}$, nor the CP proteins showed more than $25 \%$ diversity, the species demarcation identity criteria for closteroviruses [15]. No two isolates, except SLO and US, shared no more than $90 \%$ amino acid identities across genes. The isolates infecting the red currant were more than $80 \%$ identical, with the exception of p13.

The divergence of BcLRaV-1 isolates resembles those observed in grapevine leafroll-associated viruses 3 and 4, members of the genus Ampelovirus [30,31], with values of $62 \%$ and $68 \%$, respectively. 
For members of the genus Closterovirus, the most distant examples could be found among CTV and GLRaV-2, with isolates sharing 79\% and 72\% nt identities, respectively. Analysis of the CP aa homologies among CTV and GLRaV-2 isolates revealed divergence comparable to BcLRaV-1 (Figure 4). A unimodal distribution was observed with peaks of $96 \%$ and $99 \%$ for CTV and GLRaV-2, respectively, whereas the BCLRaV-1 profile differed, with the majority of values being in the 76-77\% region. It should be noted that the BcLRaV-1 analysis is only based on five isolates, unlike the other two viruses, where the analyses were based on hundreds.

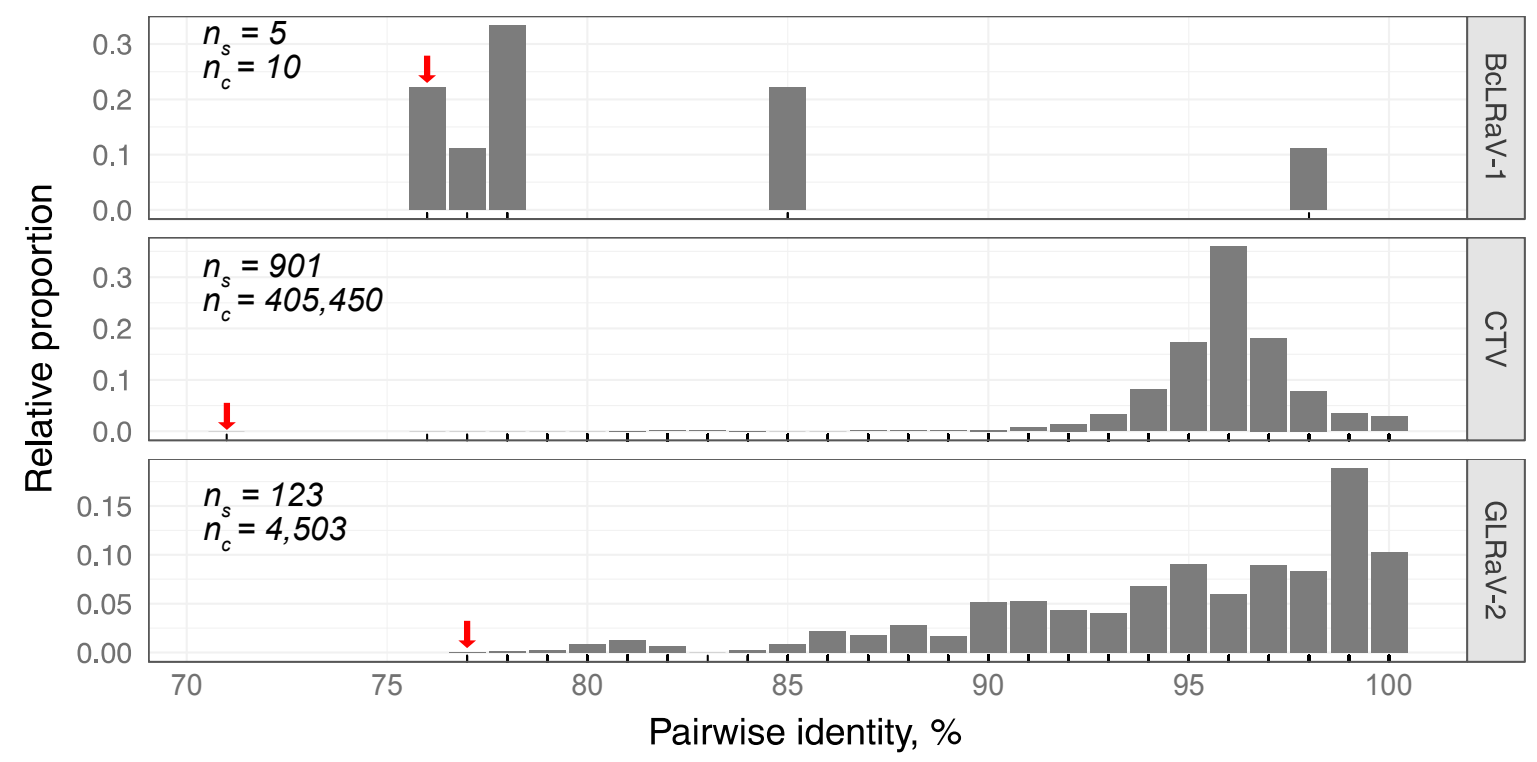

Figure 4. Distribution of the pairwise amino acid CP sequence homologies of BcLRaV-1, GLRaV-2, and CTV isolates. Complete protein sequences were obtained from GenBank (June 2018). The number of analyzed sequences (ns) and their pairwise combinations (nc) are shown. The lowest identity value is indicted by a red arrow. Additionally, the positions of the data points along the $x$ axes are denoted by tick marks.

Interestingly, the 5'- and $3^{\prime}$-untranslated regions (UTRs) showed considerable divergence, with $65-81 \%$ and $56-76 \%$ of positions being conserved, respectively. For comparison, CTV isolates show only $60-70 \%$ nt identity in $5^{\prime}$-UTRs [32].

\subsection{Phylogenetic Analysis}

A maximum likelihood phylogenetic inference of the aa sequences of $1 \mathrm{~b}$ and $\mathrm{CP}$ of the five isolates and representative members of the family confirmed the taxonomical status of BcLRaV-1 in the Closterovirus genus (Figure 5). Phylogenetic trees based on the $1 \mathrm{~b}$ and CP sequences (Figure 5a,b) showed a clear separation of BcLRaV-1 from other members of the genus, whereas analysis based on the HSP70h sequences (Figure 5c) supported its clustering with strawberry chlorotic fleck-associated virus, raspberry leaf mottle virus, rose leaf rosette-associated virus, and CTV. The branching topology of the BcLRaV-1 isolates showed some discrepancy. Black and red currant isolates were clustered separately in the CP and HSP70h trees (Figure 5b,c), but were mixed in the 1b tree, with BC28074 grouping with the red currant isolates (Figure 5a). The fact that divergent topologies produced the different genes pointed to recombination. To test this hypothesis, a recombination analysis was performed. 

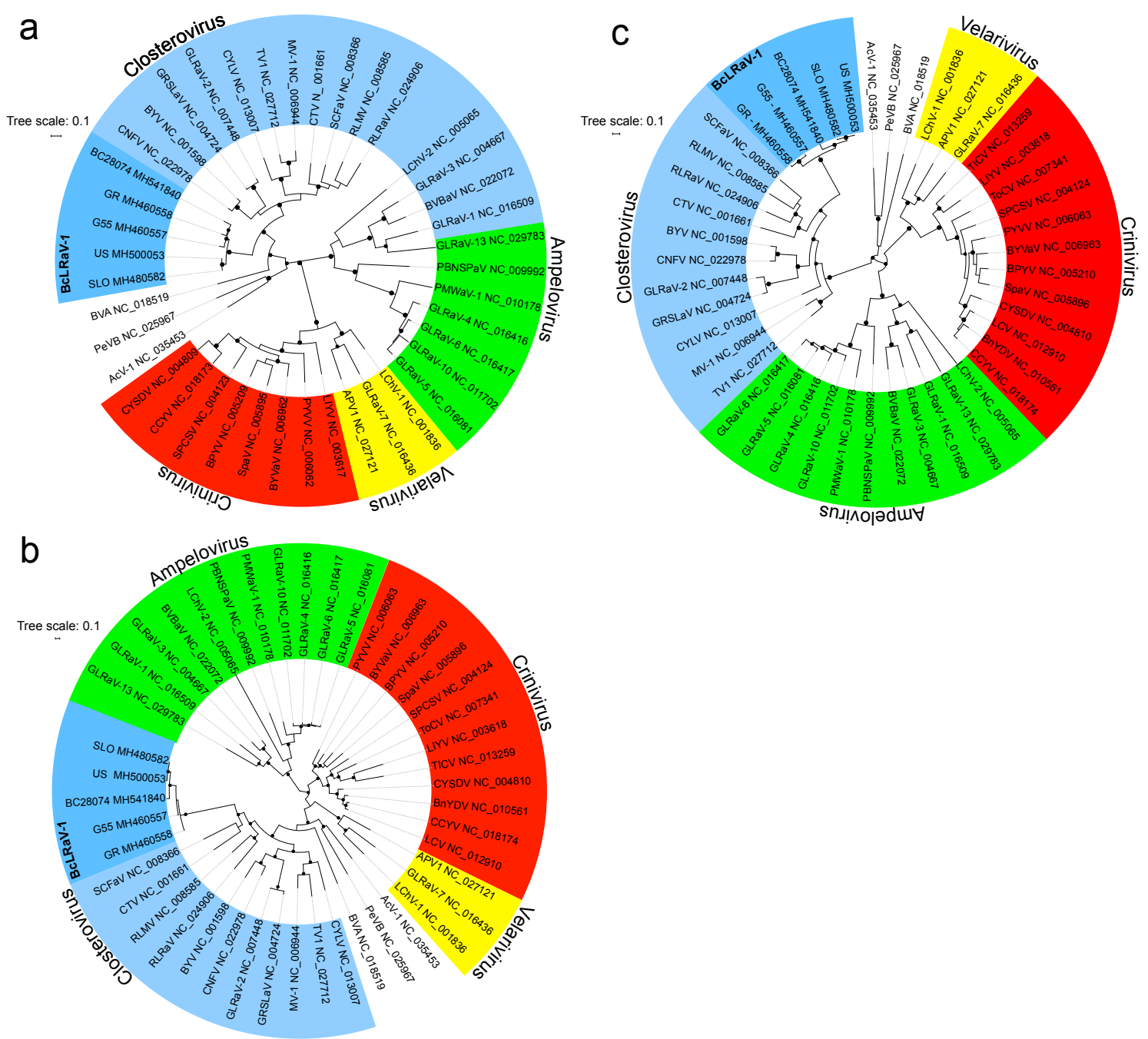

Figure 5. Phylogenetic analysis of the aligned amino acid sequences of (a) the polymerase (ORF2, 1b), (b) the coat protein (ORF6), and (c) HSP70h (ORF4). Branching support with values more than $80 \%$ is indicated by dots. Amino acid sequences used in the analysis were obtained from Genbank for the following members of the family Closteroviridae: actinidia virus 1 (AcV-1), areca palm velarivirus 1 (APV1), bean yellow disorder virus (BnYDV), beet pseudoyellows virus (BPYV), blackberry vein banding-associated virus (BVBaV), blackberry yellow vein-associated virus (BYVaV), blueberry virus A (BVA), carnation yellow fleck virus (CNFV), cucurbit chlorotic yellows virus (CCYV), cucurbit yellow stunting disorder virus (CYSDV), grapevine leafroll-associated virus 1 (GLRaV-1), grapevine leafroll-associated virus 3 (GLRaV-3), grapevine leafroll-associated virus 4 (GLRaV-4), grapevine leafroll-associated virus 5 (GLRaV-5), grapevine leafroll-associated virus 6 (GLRaV-6), grapevine leafroll-associated virus 7 (GLRaV-7), grapevine leafroll-associated virus 10 (GLRaV-10), grapevine leafroll-associated virus 13 (GLRaV-13), lettuce chlorosis virus (LCV), lettuce infectious yellows virus (LIYV), little cherry virus 1 (LChV-1), little cherry virus 2 (LChV-2), persimmon virus B (PeVB), pineapple mealybug wilt-associated virus 1 (PMWaV-1), plum bark necrosis stem pitting-associated virus (PBNSPaV), potato yellow vein virus (PYVV), raspberry leaf mottle virus (RLMV), strawberry pallidosis-associated virus (SpaV), sweet potato chlorotic stunt virus (SPCSV), tomato chlorosis virus (ToCV), tomato infectious chlorosis virus (TICV).

\subsection{Recombination Analysis}

Recombination events supported by at least six of the nine algorithms applied in RDP4 [21] were considered as possible events (Table 3; complete list in shown in Supplementary Material). 
Significant evidence of three events was found (Table 3). For the US isolate, the recombinant region covered a part of ORF2 (1b protein) and stretched to ORF3 (p6 protein), involving the BC28074 and GR lineages as major and minor parents, respectively. In contrast, G55 is a product of a recombination event between the US and GR lineages, with a predicted recombinant area covering almost the entirety of the $1 \mathrm{a} / 1 \mathrm{~b}$ coding area (Table 3$)$.

Table 3. Recombination analysis of BcLRaV-1 isolates.

\begin{tabular}{|c|c|c|c|c|c|c|c|c|c|c|c|c|}
\hline \multirow[b]{2}{*}{$\begin{array}{l}\text { Predicted } \\
\text { Recombinant } \\
\text { Isolate }\end{array}$} & \multirow[b]{2}{*}{$\begin{array}{l}\text { Position of the } \\
\text { Recombinant Part } \\
\text { (Predicted } \\
\text { Breakpoints) }\end{array}$} & \multicolumn{2}{|c|}{$\begin{array}{l}\text { Putative Parental } \\
\text { Isolates }{ }^{1}\end{array}$} & \multicolumn{9}{|c|}{ Detection Method } \\
\hline & & $\begin{array}{l}\text { Major } \\
\text { Parent }\end{array}$ & $\begin{array}{l}\text { Minor } \\
\text { Parent }\end{array}$ & 宅 & 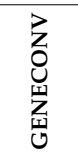 & $\begin{array}{l}\text { ฮू } \\
\text { ڤ̊ } \\
\stackrel{0}{0}\end{array}$ & 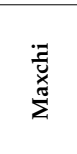 & 离 & $\begin{array}{l}\text { हू } \\
\text { क् } \\
\text { के }\end{array}$ & $\frac{2}{\sqrt{2}}$ & 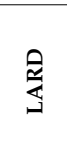 & घ్ \\
\hline G55 & $45-9957$ & $\begin{array}{l}\text { Unknown } \\
\text { (US) }\end{array}$ & GR & $\begin{array}{c}1.1 \times \\
10^{-52}\end{array}$ & $\mathrm{NS}^{2}$ & $\begin{array}{l}5.1 \times \\
10^{-40}\end{array}$ & $\begin{array}{l}2.2 \times \\
10^{-15}\end{array}$ & $\begin{array}{l}4.6 \times \\
10^{-33}\end{array}$ & $\begin{array}{l}2.3 \times \\
10^{-84}\end{array}$ & $\mathrm{NS}^{2}$ & $\mathrm{NS}^{2}$ & $\begin{array}{l}1.6 \times \\
10^{-5}\end{array}$ \\
\hline US & $7701-10,345$ & BC28074 & GR & $\begin{array}{l}2.7 \times \\
10^{-5}\end{array}$ & $\mathrm{NS}^{2}$ & $\begin{array}{l}2.3 \times \\
10^{-2}\end{array}$ & $\begin{array}{l}1.5 \times \\
10^{-4}\end{array}$ & $\begin{array}{l}7.5 \times \\
10^{-6}\end{array}$ & $\begin{array}{l}5.8 \times \\
10^{-4}\end{array}$ & $\mathrm{NS}^{2}$ & $\begin{array}{l}4.3 \times \\
10^{-51}\end{array}$ & $\begin{array}{l}2.2 \times \\
10^{-5}\end{array}$ \\
\hline US & $4514-4729$ & GR & G55 & $\begin{array}{l}1.0 \times \\
10^{-3}\end{array}$ & $\begin{array}{l}2.5 \times \\
10^{-2}\end{array}$ & $\begin{array}{l}7.2 \times \\
10^{-3}\end{array}$ & $\mathrm{NS}^{2}$ & $\begin{array}{l}4.3 \times \\
10^{-2}\end{array}$ & $\begin{array}{l}8.5 \times \\
10^{-9}\end{array}$ & $\mathrm{NS}^{2}$ & $\mathrm{NS}^{2}$ & $\begin{array}{l}4.1 \times \\
10^{-2}\end{array}$ \\
\hline
\end{tabular}
${ }^{1}$ Major and minor parents-predicted contribution of the larger and smaller sequence fragments, respectively, ${ }^{2}$
NS-no support detected.

Recombination is one of the mechanisms facilitating viral evolution. For several closteroviruses and ampeloviruses, recombination events have been identified [14,33]. Isolates from black or red currant were involved in the recombination process, suggesting a complex evolutionary history for BcLRaV-1. The number of analyzed isolates was, however, too low to trace any patterns in diversity and their possible relationships. A further, thorough investigation should involve additional whole-genome sequences, given the possible misidentification of potential recombinant sequences (one of the identified parents might be of recombinant origin; see Supplementary Material).

\subsection{Transmission Electron Microscopy}

After particle purification of BC28074-positive leaf material showing leafroll symptoms (Figure 6a), long thread-like particles were visualized (Figure 6b), typical for members of the family Closteroviridae [15], with the most frequent length being $1500 \mathrm{~nm}$ and the most frequent width being ca. $11 \mathrm{~nm}(n=125)$.

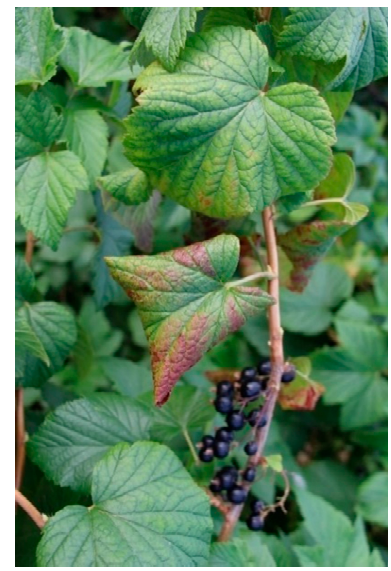

(a)

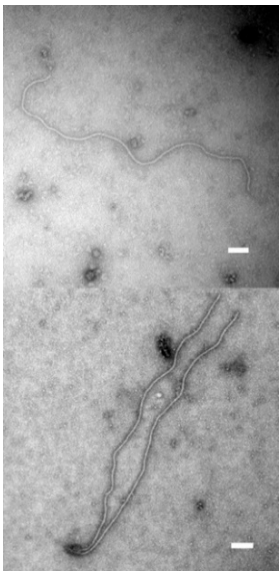

(b)

Figure 6. (a) Leafroll symptoms on the black currant plant, 28074: downward curling of leaf margins and interveinal red coloration (Switzerland, July 2017); (b) individual particles obtained after viral particle enrichment of the black currant 28074 leaf material. The scale bar represents $100 \mathrm{~nm}$. 


\section{Conclusions}

Several diverse closterovirid isolates were identified in the currant in Europe and North America. Sequence analyses of the whole genome, as well as phylogenetic inference, confirmed that they all belonged to a novel species of the genus Closterovirus, family Closteroviridae, tentatively named blackcurrant leafroll associated virus 1 (BcLRaV-1). The presence of the virus was further confirmed using electron microscopy and via sequencing of RT-PCR amplicons. Sequence comparison of all genes revealed high molecular variability across isolates (Figure 3), with p13, a protein of unknown function, being the least conserved. The phylogenetic analyses of selected proteins revealed topological differences between the trees based on the $1 \mathrm{~b}$ and CP/HSP70h (Figure 5), potentially presenting the evidence of potential intraspecies recombination events. Indeed, several possible recombination points were located between the black and red currant isolates (Table 3). This may indicate complex transmission routes that enabled the coinfection of a single host by the hypothetical parental genomes in the past. Nevertheless, recombination analysis involving a wider dataset is required to understand the evolutionary process giving rise to the virus genome.

The nearly identical US and SLO isolates (Figure 3) may reflect a long-distance movement of virus-infected Ribes plants. Further investigation should evaluate whether or not the divergent isolates have different pathogenicity capacities.

Supplementary Materials: The following are available online at http:/ / www.mdpi.com/1999-4915/10/7/369/s1, Table S1: Recombination analysis of BcLRaV-1 isolates.xslx.

Author Contributions: Ig.K., J.Š., I.M.P., J-S.R., T.H., and I.E.T. conceived and designed the experiments; Ig.K., T.S., J.P., I.M.P., J-S.R., J.L., T.H., and T.T.-V. performed the experiments; Ig.K., I.M.P., J.S.R., J.L., T.T.-V., and I.E.T. analyzed the data; Ig.K. wrote the paper. All authors revised the paper. All authors discussed the results and contributed to the final manuscript.

Funding: This research was funded by USDA awards 14-8130-0420-CA and 14-8130-0392-CA, institutional support from RVO 60077344, COST Action grant number FA1407 (DIVAS), and Slovenian Research Agency grant P4-0072.

Acknowledgments: The authors would like to thank Jitka and Pascal Kissling and Alenor Conservation garden, Horní Záblatí 31, CZ-384 33 Záblatí, Czech Republic, for their kind collaboration and access to their Ribes germplasm collection. The black currant plant with BcLRaV-SLO originated from the germplasm collection of the Agricultural Institute of Slovenia at Brdo pri Lukovici. The technical assistance of N. Dubuis, L. Grosu-Duchêne, Alena Matyášová, and Barbara Grubar is gratefully acknowledged.

Conflicts of Interest: The authors declare no conflict of interest. The funders had no role in the design of the study; in the collection, analyses, or interpretation of data; in the writing of the manuscript; or in the decision to publish the results.

\section{References}

1. Mitchell, C.; Brennan, R.M.; Cross, J.V.; Johnson, S.N. Arthropod pests of currant and gooseberry crops in the U.K.: Their biology, management and future prospects. Agric. For. Entomol. 2011, 13, 221-237. [CrossRef]

2. Geils, B.W.; Hummer, K.E.; Hunt, R.S. White pines, Ribes, and blister rust: A review and synthesis. For. Pathol. 2010, 40, 147-185. [CrossRef]

3. Adams, A.N.; Thresh, J.M. Reversion of black currant. In Virus Disease of Small Fruits; Converse, R.H., Ed.; United States Department of Agriculture: Washington, DC, USA, 1987; pp. 133-136.

4. Jones, A.T. Black currant reversion disease-The probable causal agent, eriophyid mite vectors, epidemiology and prospects for control. Virus Res. 2000, 71, 71-84. [CrossRef]

5. Jones, A.T.; McGavin, W.J.; Geering, A.D.W.; Lockhart, B.E.L. A new badnavirus in Ribes species, its detection by PCR, and its close association with gooseberry vein banding disease. Plant Dis. 2001, 85, 417-422. [CrossRef]

6. Besse, S.; Gugerli, P.; Ramel, M.E.; Balmelli, C. Characterisation of mixed virus infections in Ribes species in Switzerland. In Proceedings of the 21st International Conference on Virus and other Graft Transmissible Diseases of Fruit Crops, Neustadt, Germany, 5-10 July 2009; pp. 214-219.

7. Ho, T.; Tzanetakis, I.E. Development of a virus detection and discovery pipeline using next generation sequencing. Virology 2014, 471-473, 54-60. [CrossRef] [PubMed] 
8. Petrzik, K.; Koloniuk, I.; Přibylová, J.; Špak, J. Complete genome sequence of currant latent virus (genus Cheravirus, family Secoviridae). Arch. Virol. 2015, 161, 1-3. [CrossRef] [PubMed]

9. Petrzik, K.; Přibylová, J.; Koloniuk, I.; Špak, J. Molecular characterization of a novel capillovirus from red currant. Arch. Virol. 2016, 161, 1083-1086. [CrossRef] [PubMed]

10. James, D.; Phelan, J. Complete genome sequence of a strain of Actinidia virus X detected in Ribes nigrum cv. Baldwin showing unusual symptoms. Arch. Virol. 2016, 161, 507-511. [CrossRef] [PubMed]

11. Wu, L.P.; Yang, T.; Liu, H.W.; Postman, J.; Li, R. Molecular characterization of a novel rhabdovirus infecting blackcurrant identified by high-throughput sequencing. Arch. Virol. 2018, 162, 2493-2494. [CrossRef] [PubMed]

12. Roberts, I.M.; Jones, A.T. Rhabdovirus-like and closterovirus-like particles in ultrathin sections of Ribes species with symptoms of blackcurrant reversion and gooseberry veinbanding diseases. Ann. Appl. Biol. 1997, 130, 77-89. [CrossRef]

13. Ho, T.; Postman, J.D.; Tzanetakis, I.E. Discovery, characterization and detection of five new virus species in Ribes. In Proceedings of the 23rd International Conference on Virus and Other Graft Transmissible Diseases of Fruit Crops, Morioka, Japan, 8-12 June 2015; PSJ Plant Virus Disease Workshop Report No. 12 (Special Edition). Phytopathological Society of Japan: Tokyo, Japan, 2016; pp. 8-10.

14. Rubio, L.; Guerri, J.; Moreno, P. Genetic variability and evolutionary dynamics of viruses of the family Closteroviridae. Front. Microbiol. 2013, 4, 1-15. [CrossRef] [PubMed]

15. Martelli, G.P.; Agranovsky, A.A.; Bar-Joseph, M.; Boscia, D.; Candresse, T.; Coutts, R.H.A.; Dolja, V.V.; Hu, J.S.; Jelkmann, W.; Karasev, A.V.; et al. Family Closteroviridae. In Ninth Report of the International Committee on Taxonomy of Viruses; King, A.M.Q., Adams, M.J., Carstens, E.B., Lefkowitz, E.J., Eds.; Elsevier Academic Press: New York, NY, USA, 2012; pp. 987-1001.

16. Gugerli, P.; Ramel, M.E. Production of monoclonal antibodies for the serological identification and reliable detection of Apple stem pitting and Pear yellow vein viruses in apple and pear. Acta Hortic. 2004, 59-69. [CrossRef]

17. Koloniuk, I.; Fránová, J.; Sarkisova, T.; Přibylová, J.; Lenz, O.; Petrzik, K.; Špak, J. Identification and molecular characterization of a novel varicosa-like virus from red clover. Arch. Virol. 2018, in press. [CrossRef] [PubMed]

18. Gugerli, P. Isopycnic centrifugation of plant-viruses in nycodenz density gradients. J. Virol. Methods 1984, 9, 249-258. [CrossRef]

19. Katoh, K.; Standley, D.M. MAFFT Multiple Sequence Alignment Software Version 7: Improvements in Performance and Usability. Mol. Biol. Evol. 2013, 30, 772-780. [CrossRef] [PubMed]

20. Letunic, I.; Bork, P. Interactive tree of life (iTOL) v3: An online tool for the display and annotation of phylogenetic and other trees. Nucleic Acids Res. 2016, 44, W242-W245. [CrossRef] [PubMed]

21. Martin, D.P.; Murrell, B.; Golden, M.; Khoosal, A.; Muhire, B. RDP4: Detection and analysis of recombination patterns in virus genomes. Virus Evol. 2015, 1, 1-5. [CrossRef] [PubMed]

22. Dolja, V.V.; Kreuze, J.F.; Valkonen, J.P.T. Comparative and functional genomics of closteroviruses. Virus Res. 2006, 117, 38-51. [CrossRef] [PubMed]

23. Peng, C.W.; Peremyslov, V.V.; Mushegian, A.R.; Dawson, W.O.; Dolja, V.V. Functional specialization and evolution of leader proteinases in the family Closteroviridae. J. Virol. 2001, 75, 12153-12160. [CrossRef] [PubMed]

24. Liu, Y.-P.; Peremyslov, V.V.; Medina, V.; Dolja, V.V. Tandem leader proteases of Grapevine leafroll-associated virus-2: Host-specific functions in the infection cycle. Virology 2009, 383, 291-299. [CrossRef] [PubMed]

25. Gushchin, V.A.; Karlin, D.G.; Makhotenko, A.V.; Khromov, A.V.; Erokhina, T.N.; Solovyev, A.G.; Morozov, S.Y.; Agranovsky, A.A. A conserved region in the Closterovirus 1a polyprotein drives extensive remodeling of endoplasmic reticulum membranes and induces motile globules in Nicotiana benthamiana cells. Virology 2016, 502, 1-8. [CrossRef] [PubMed]

26. Koonin, E.V.; Dolja, V.V. Evolution and taxonomy of positive-strand RNA viruses: Implications of comparative analysis of amino acid sequences. Crit. Rev. Biochem. Mol. Biol. 1993, 28, 375-430. [CrossRef] [PubMed]

27. Erokhina, T.N.; Zinovkin, R.A.; Vitushkina, M.V.; Jelkmann, W.; Agranovsky, A.A. Detection of beet yellows closterovirus methyltransferase-like and helicase-like proteins in vivo using monoclonal antibodies. J. Gen. Virol. 2000, 81, 597-603. [CrossRef] [PubMed] 
28. Peremyslov, V.V.; Pan, Y.W.; Dolja, V.V. Movement protein of a closterovirus Is a type III integral transmembrane protein localized to the endoplasmic reticulum. J. Virol. 2004, 78, 3704-3709. [CrossRef] [PubMed]

29. Lu, R.; Folimonov, A.; Shintaku, M.; Li, W.-X.; Falk, B.W.; Dawson, W.O.; Ding, S.-W. Three distinct suppressors of RNA silencing encoded by a 20-kb viral RNA genome. Proc. Natl. Acad. Sci. USA 2004, 101, 15742-15747. [CrossRef] [PubMed]

30. Reynard, J.-S.; Schneeberger, P.H.H.; Frey, J.E.; Schaerer, S. Biological, serological, and molecular characterization of a highly divergent strain of Grapevine leafroll-associated virus 4 causing grapevine leafroll disease. Phytopathology 2015, 105, 1262-1269. [CrossRef] [PubMed]

31. Štrukelj, M.; Pleško, I.M.; Urek, G. Molecular characterization of a grapevine leafroll-associated virus 4 from Slovenian vineyards. Acta Virol. 2016, 60, 174-180. [CrossRef] [PubMed]

32. Bar-Joseph, M.; Dawson, W.O. Citrus Tristeza Virus. In Desk Encyclopedia of Plant and Fungal Virology; Mahy, B.W.J., van Regenmortel, M.H.V., Eds.; Academic Press: San Diego, CA, USA, 2009; pp. 160-165.

33. Martín, S.; Sambade, A.; Rubio, L.; Vives, M.C.; Moya, P.; Guerri, J.; Elena, S.F.; Moreno, P. Contribution of recombination and selection to molecular evolution of Citrus tristeza virus. J. Gen. Virol. 2009, 90, 1527-1538. [CrossRef] [PubMed]

(C) 2018 by the authors. Licensee MDPI, Basel, Switzerland. This article is an open access article distributed under the terms and conditions of the Creative Commons Attribution (CC BY) license (http:/ / creativecommons.org/licenses/by/4.0/). 